\title{
m-Azido-Phencyclidine Covalently Labels the Rat Brain PCP Receptor, a Putative K Channel
}

\author{
Roger G. Sorensen and Mordecai P. Blaustein \\ Department of Physiology, University of Maryland School of Medicine, Baltimore, Maryland 21201
}

Phencyclidine (PCP) is a schizophrenomimetic drug of abuse. PCP binds with high affinity (apparent dissociation constant, $\left.K_{\mathrm{D}}<10^{-6} \mathrm{M}\right)$ to rat brain membranes and blocks, selectively, a voltage-gated, noninactivating $K$ channel found in rat brain synaptosomes (presynaptic nerve terminals). Thus, it has been proposed that the high-affinity PCP receptor in brain is this $K$ channel. Consistent with this hypothesis, we now show that several $K$ channel blockers displace ${ }^{3} \mathrm{H}-\mathrm{PCP}$ from the rat brain receptor. Additionally, we have used a photolabile analog of PCP, $m$-azido-PCP (Az-PCP), to identify the brain PCP receptor/putative $K$ channel.

In the dark, Az-PCP bound reversibly to 2 classes of sites on rat brain synaptic membranes $\left[K_{\mathrm{D}}=0.14 \pm 0.01 \mu \mathrm{M}(n=5)\right.$ for high-affinity binding, and $K_{\mathrm{D}}=255 \pm 55 \mu \mathrm{M}$ for low-affinity binding]. Competitive binding studies between $A z^{-3} \mathrm{H}-\mathrm{PCP}$ and nonlabeled PCP analogs, and between Az-PCP and several tritiated PCP analogs, indicated that the high-affinity Az-PCP binding site is the high-affinity PCP receptor. Several aminopyridines (APs) and tetraalkylamines (TAAs), which are known to block $K$ channels in excitable cells, were also found to displace ${ }^{3} \mathrm{H}-\mathrm{PCP}$ from its high-affinity binding site on rat brain synaptic membranes. The rank order of potency for displacement of ${ }^{3} \mathrm{H}$-PCP from this site for the APs was 4-AP $\simeq 3,4-$ diAP $>2$-AP $\gg 3-A P$; for the TAAs it was TBA $>$ TEA $\gg$ TMA (the tetra-butyl, ethyl, and methyl amines, respectively). These sequences parallel those observed for block of some $K$ channels and/or enhancement of neurotransmitter release.

$\mathrm{Az}^{-3} \mathrm{H}-\mathrm{PCP}$ was covalently attached to rat brain membranes by photoactivation; subsequent separation of the membrane polypeptides by SDS-PAGE, followed by fluorography, revealed that several polypeptides incorporated the label. Labeling of 2 polypeptides, with apparent molecular weights of 95,000 and 80,000 , was blocked by PCP and by its behaviorally active thienyl analog, TCP, with little reduction of the label incorporated onto any other polypeptide. 4-AP and TBA also specifically blocked the covalent attachment of $A z-{ }^{3} \mathrm{H}-P C P$ to the 95 and $80 \mathrm{kDa}$ polypeptides. We therefore conclude that the highaffinity PCP receptor in rat brain consists of 95 and $80 \mathrm{kDa}$ polypeptides and that these 2 polypeptides are also components of a voltage-gated $K$ channel.

Phencyclidine (1-[1-phenylcyclohexyl] piperidine; $\mathrm{PCP}$ ) is a dissociative anesthetic and drug of abuse that in man produces a

\footnotetext{
Received Mar. 11, 1986; revised June 3, 1986; accepted June 6, 1986.

We are grateful to Mr. A. Marvel for expert technical assistance. We thank Drs. D. Burt and B. K. Krueger for very helpful discussion, Drs. Krueger, R. Bloch and D. K. Bartschat for critique of a preliminary version of the manuscript, and Dr. M. Sokolovsky for providing preprints of work from his laboratory. We also thank Ms. A. Wilder for preparation of the typescript. We are grateful to Dr. R. L. Post for his generous gift of purified dog kidney Na,K-ATPase, and to NIDA for supplies of PCP, TCP, and $m$-amino PCP. This work was supported by NIH NRSA NS07611 to R.G.S. and NIH Grant NS16106 to M.P.B.

Correspondence should be addressed to Dr. Mordecai P. Blaustein, Department of Physiology, University of Maryland School of Medicine, $655 \mathrm{~W}$. Baltimore Street, Baltimore, MD 21201.

Copyright (c) 1986 Society for Neuroscience $0270-6474 / 86 / 123676-06 \$ 02.00 / 0$
}

toxic psychosis with many schizophrenia-like symptoms (Domino and Luby, 1981). A high-affinity (apparent $K_{\mathrm{D}}<10^{-6} \mathrm{M}$ ) binding site for PCP has been described in rat brain (Blaustein and Ickowicz, 1983; Hampton et al., 1982; Mendelsohn et al., 1984; Vincent et al., 1983; Zukin et al., 1983). This receptor appears to be responsible for the abnormal behavior induced by PCP because the affinities of PCP and its analogs for binding to the brain receptor correlate with their behavioral potencies (Lazdunski et al., 1983; Mendelsohn et al., 1984; Zukin and Zukin, 1979).

PCP and its analogs have been shown to block selectively a voltage-gated, noninactivating $\mathrm{K}$ channel that is present in isolated rat brain presynaptic nerve terminals (synaptosomes) (Bartschat and Blaustein, 1986a). Selective block of this channel by "sigma" opiates with PCP-like activity has also been observed (Bartschat and Blaustein, 1986b). The potencies of PCP and its analogs for block of this $\mathrm{K}$ channel correlate with the affinities of these compounds for binding to the high-affinity receptor (Bartschat and Blaustein, 1986a). Likewise, the stereospecificities of "sigma" opiates for inhibition of high-affinity ${ }^{3} \mathrm{H}-\mathrm{PCP}$ binding (Bartschat et al., 1985; Mendelsohn et al., 1984) and for block of the voltage-gated, noninactivating $\mathrm{K}$ channel (Bartschat and Blaustein, 1986b) are similar. Thus, it was proposed that the high-affinity $\mathrm{PCP}$ receptor in the brain may be this K channel (Bartschat and Blaustein, 1986a; Blaustein and Ickowicz, 1983).

In an effort to identify the mammalian brain PCP receptor, we employed an approach similar to that already used successfully to label the PCP receptor in Torpedo membranes (Haring et al., 1984; Heidmann et al., 1985). We synthesized a photolabile analog of PCP, Az-PCP, in both nonradiolabeled and tritiated $\left(\mathrm{Az}^{-3} \mathrm{H}-\mathrm{PCP}\right)$ forms. Our data indicate that this agent binds with high affinity to the $\mathrm{PCP}$ receptor of rat forebrain. Photolabeling with $\mathrm{Az}-{ }^{3} \mathrm{H}-\mathrm{PCP}$ results in the specific incorporation of label onto 2 polypeptides; covalent labeling is blocked by PCP and by its thienyl analog TCP. The idea that the brain PCP receptor is a $\mathrm{K}$ channel is supported by our observation that 2 known $\mathrm{K}$ channel blockers, 4-aminopyridine (4-AP) and tetrabutylammonium (TBA), also block ${ }^{3} \mathrm{H}$-PCP binding to the high-affinity sites on synaptic membranes and block the covalent attachment of Az- ${ }^{3} \mathrm{H}-\mathrm{PCP}$ onto the same 2 polypeptides, selectively. Some of these findings have been presented in preliminary form (Sorensen and Blaustein, 1985a, b).

\section{Materials and Methods}

\section{Materials}

${ }^{3} \mathrm{H}-\mathrm{PCP}(49.9 \mathrm{Ci} / \mathrm{mmol})$ was obtained from New England Nuclear (Boston, MA); ${ }^{3} \mathrm{H}-1$-(1-thienylcyclohexyl) piperidine $\left({ }^{3} \mathrm{H}-\mathrm{TCP} ; 64 \mathrm{Ci} / \mathrm{mmol}\right)$ was obtained from New England Nuclear or from Research Products International (Mt. Prospect, IL). Amino- ${ }^{3} \mathrm{H}-\mathrm{PCP}(18 \mathrm{Ci} / \mathrm{mmol})$ was custom tritiated by Amersham (Arlington Heights, IL). Unlabeled PCP, TCP, and amino-PCP were obtained from the National Institute on Drug Abuse (NIDA). HEPES, Tris, AP analogs, and tetraalkylamine (TAA) analogs were obtained from Sigma Chemical Co. (St. Louis, MO) 4-AP was also obtained from Aldrich Chemical Co. (Milwaukee, WI). 


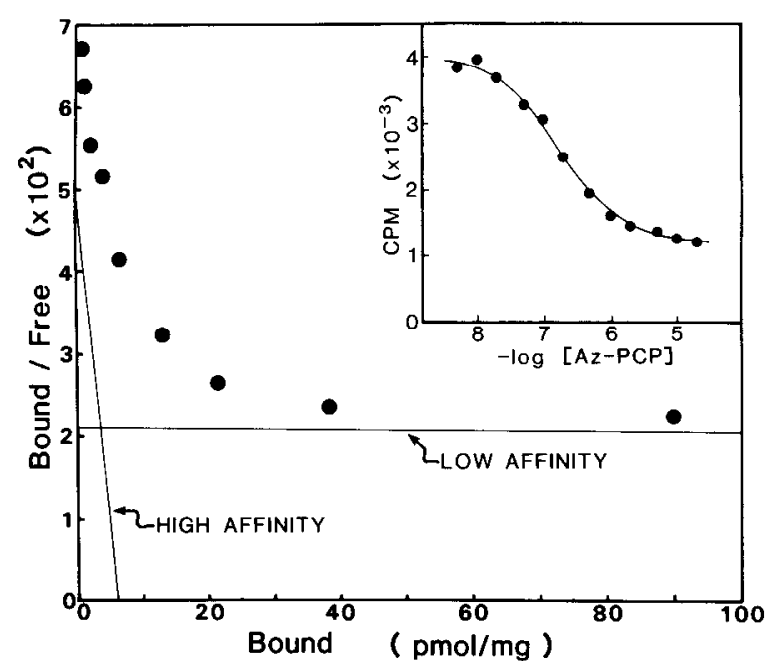

Figure 1. Binding of $\mathrm{Az}^{3} \mathrm{H}-\mathrm{PCP}$ to rat brain synaptic membranes. The graph is the Scatchard plot calculated from data from a representative experiment in which the binding parameters were determined from the displacement of $\mathrm{Az}-{ }^{3} \mathrm{H}-\mathrm{PCP}$ by unlabeled Az-PCP. To illustrate the high-affinity binding clearly, the 2 data points obtained with the highcst concentrations of unlabeled Az-PCP (points at 1 and $2 \times$ $10^{-5} \mathrm{M}$; see inset), which fall on the "low affinity" line, have been omitted. Plotted values were calculated from the displacement curve data (means of triplicate determinations) shown in the inset. The values were fitted to a 2-site model by computer-assisted curve-fitting analysis (Munson and Rodbard, 1980); the 2 calculated curves for the binding sites (high and low affinity) are indicated. The calculated binding parameters for this experiment were: high affinity, $K_{\mathrm{D}}=0.147 \mu \mathrm{M}, B_{\max }=$ $6.0 \mathrm{pmol}$ ligand $/ \mathrm{mg}$ protein; low affinity, $K_{\mathrm{D}}=225 \mu \mathrm{M}, B_{\max }=3863$ $\mathrm{pmol}$ ligand $/ \mathrm{mg}$ protein.

\section{Preparation of $A z-P C P$ and $A z-{ }^{3} H-P C P$}

Az-PCP was prepared by diazotization of $m$-amino-PCP. All reaction mixtures were kept on ice. $m$-Amino-PCP $(10 \mathrm{mg}, 0.039 \mathrm{mmol})$ was dissolved in $10 \mathrm{ml}$ of $3 \mathrm{~N}$ acetic acid. $\mathrm{NaNO}_{2}(3.2 \mathrm{mg}$ in $0.5 \mathrm{ml}, 1.2$ equiv.) was added, followed, after $15 \mathrm{~min}$, by $\mathrm{NaN}_{3}(3.3 \mathrm{mg}$ in $0.5 \mathrm{ml}$, 1.3 equiv.). After an additional $15 \mathrm{~min}$, the mixture was neutralized with $4 \mathrm{ml}$ concentrated $\mathrm{NaOH}$ and then extracted with $\mathrm{CHCl}_{3}(3 \times 5$ $\mathrm{ml}$ ); the $\mathrm{CHCl}_{3}$ extract was dried over $\mathrm{MgSO}_{4}$ and evaporated to dryness under $\mathrm{N}_{2}$. Az-PCP was stored in absolute ethanol. Successful incorporation of the azido moiety was determined from the UV absorbance spectrum of the compound. The absorbance spectrum of Az-PCP (maximum at $255 \mathrm{~nm}$ ) changed upon photoactivation of the compound with UV light - this is characteristic of azido compounds (DeTraglia et al., 1978) - whereas the absorbance spectrum of amino-PCP (maximum at $250 \mathrm{~nm}$ ) was unchanged after UV irradiation. The compound ran as a single spot during thin-layer chromatography on silica gel [solvent systems: methanol/ $\mathrm{NH}_{4} \mathrm{OH}(99: 1), R_{\mathrm{f}}=0.68$; and $n$-butanol/acetic acid/ $\left.\mathrm{H}_{2} \mathrm{O}(25: 8: 10), R_{\mathrm{f}}=0.47\right]$.

A similar but scaled-down procedure was used to prepare $\mathrm{Az}_{-}{ }^{3} \mathrm{H}$ PCP. Amino- ${ }^{3} \mathrm{H}-\mathrm{PCP}(1 \mathrm{mCi} ; 0.056 \mu \mathrm{mol})$ was dried under $\mathrm{N}_{2}$ and dissolved in $20 \mu \mathrm{l}$ of $3 \mathrm{~N}$ acctic acid. $\mathrm{NaNO}_{2}(6.5 \mu \mathrm{g}$ in $1 \mu \mathrm{l})$ and $\mathrm{NaN}_{3}$ $(6.6 \mu \mathrm{g}$ in $1 \mu \mathrm{l})$ were added as described above. The mixture was neutralized with $8 \mu$ l concentrated $\mathrm{NH}_{4} \mathrm{OH}$, extracted with $\mathrm{CHCl}_{3}(3 \times 100$ $\mu \mathrm{l})$, and dried over $\mathrm{MgSO}_{4}$. The $\mathrm{Az}-{ }^{-3} \mathrm{H}-\mathrm{PCP}$ was evaporated to dryness under $\mathrm{N}_{2}$ and stored in absolute ethanol. Az- ${ }^{3} \mathrm{H}-\mathrm{PCP}$ comigrated with $\mathrm{Az}-\mathrm{PCP}$ on thin layer chromatography.

\section{Ligand binding assay}

Ligand binding was measured by determining the concentration of unlabeled ligand required to displace a tritiated ligand. Synaptic membranes were prepared from rat forebrain by the method of Salvaterra and Matthews (1980). The membranes were incubated at $37^{\circ} \mathrm{C}$ in 20 mM Tris/HEPES, $\mathrm{pH} 7.0$, containing a constant amount of tritiated ligand and increasing amounts of the unlabeled compounds (as indicated in the tables and figure legends) in a total volume of $0.5 \mathrm{ml}$. When Az-
Table 1. Binding of PCP analogs to the rat brain high-affinity PCP receptor

\begin{tabular}{llll} 
& & \multicolumn{2}{l}{$\begin{array}{l}\text { Binding parameters for dis- } \\
\text { placement of }{ }^{3} \mathrm{H}-\text { labeled ligand }\end{array}$} \\
\cline { 3 - 4 } $\begin{array}{l}\text { Test } \\
\text { compound }\end{array}$ & ${ }^{3} \mathrm{H}$-labeled ligand & $\begin{array}{l}K_{0.5} \\
(\mu \mathrm{M})\end{array}$ & $\begin{array}{l}B_{\max } \\
\text { (pmol/mg } \\
\text { protein) }\end{array}$ \\
\hline TCP & ${ }^{3} \mathrm{H}-\mathrm{TCP}$ & $0.023 \pm 0.006$ & $2.3 \pm 0.2(3)^{a}$ \\
& $\mathrm{Az}-{ }^{3} \mathrm{H}-\mathrm{PCP}$ & 0.031 & 5.0 \\
$m$-amino-PCP & $m$-amino- ${ }^{3} \mathrm{H}-\mathrm{PCP}$ & 0.043 & 2.9 \\
& $\mathrm{Az}-{ }^{3} \mathrm{H}-\mathrm{PCP}$ & 0.055 & 4.3 \\
PCP & ${ }^{3} \mathrm{H}-\mathrm{PCP}$ & $0.065 \pm 0.005$ & $2.8 \pm 0.3(5)^{a}$ \\
& $\mathrm{Az}-{ }^{3} \mathrm{H}-\mathrm{PCP}$ & $0.088 \pm 0.005$ & $5.9 \pm 0.7(3)^{a}$ \\
Az-PCP & $\mathrm{Az}-{ }^{3} \mathrm{H}-\mathrm{PCP}$ & $0.139 \pm 0.011$ & $5.9 \pm 0.6(5)^{a}$ \\
& ${ }^{3} \mathrm{H}-\mathrm{PCP}$ & $0.180 \pm 0.012$ & $2.3 \pm 0.4(4)^{a}$ \\
& ${ }^{3} \mathrm{H}-\mathrm{TCP}$ & 0.148 & 2.3 \\
& $m$-amino- ${ }^{3} \mathrm{H}-\mathrm{PCP}$ & 0.183 & 1.8
\end{tabular}

The ability of unlabeled (test) compounds to displace tritium-labeled ligands was determined as described in Materials and Methods. The binding mixtures contained $20 \mathrm{~mm}$ Tris/HEPES, $\mathrm{pH} 7.0$, increasing amounts of the test compound, and either $5 \mathrm{~nm}{ }^{3} \mathrm{H}-\mathrm{PCP}, 5 \mathrm{~nm} \mathrm{Az}-{ }^{3} \mathrm{H}-\mathrm{PCP}, 5 \mathrm{~nm} m$-amino- ${ }^{-} \mathrm{H}-\mathrm{PCP}$, or $2.5 \mathrm{~nm}{ }^{3} \mathrm{H}-\mathrm{TCP}$, as indicated. The $K_{0,5}$ values $(\mu \mathrm{M})$ are the apparent half-maximal binding constants for the displacing (unlabeled) compound; $B_{\max }$ values (pmol ligand bound $/ \mathrm{mg}$ membrane protein) indicate the estimated number of high-affinity binding sites for the labeled ligand.

${ }^{a}$ Data are means \pm SEM of 3-5 experiments as indicated in parentheses.

$\mathrm{PCP}$ or $\mathrm{Az}-{ }^{3} \mathrm{H}-\mathrm{PCP}$ was present in the binding mixture, the assay was performed in the dark to avoid photolysis. Binding reactions were initiated by the addition of membranes (usually $600 \mu \mathrm{g}$ protein). After 30 min to allow the mixtures to reach equilibrium, $4 \mathrm{ml}$ of cold wash buffer (20 mM Tris/HEPES, pH 7.0) was added to the tubes, and the contents were rapidly applied to Whatman GF/B filters presoaked in $0.1 \%$ polyethyleneimine to reduce nonspecific binding (Hampton et al., 1982). The filters and retained membranes were washed twice with $4 \mathrm{ml}$ of the same wash buffer and counted for ${ }^{3} \mathrm{H}$ by liquid scintillation spectroscopy. Each assay was carried out in triplicate. Appropriate blank, protein-free values for each data point were subtracted from the counts obtained in the presence of protein.

\section{Photolabeling procedure}

To identify the individual membrane polypeptides to which $\mathrm{Az}-{ }^{3} \mathrm{H}-\mathrm{PCP}$ covalently attached, synaptic membranes were incubated in the dark at $0^{\circ} \mathrm{C}$ in either $5 \mathrm{~mm}$ Tris/HEPES, pH 7.0, or $10 \mathrm{~mm}$ sodium phosphate, $\mathrm{pH} 7.0$, containing $1.0 \mu \mathrm{M} \mathrm{Az}-{ }^{3} \mathrm{H}-\mathrm{PCP}$ and various test compounds. After $60 \mathrm{~min}$, the suspensions were filtered and washed as described above for the ligand binding assay. The washed filters were irradiated for $5 \mathrm{~min}$ under shortwave $(254 \mathrm{~nm})$ or for $15 \mathrm{~min}$ under long-wave $(366 \mathrm{~nm})$ UV light with a fixed $15 \mathrm{~W}$ UV lamp source (Ultra-Violet Products, Inc., San Gabriel, CA) at a distance of $6-8 \mathrm{~cm}$ to promote covalent attachment of the ligand. (Fssentially identical results were obtained with irradiation at the 2 wavelengths.) The filters were incubated overnight in SDS-dissociation buffer $(5 \mathrm{~mm}$ Tris, $\mathrm{pH} 8.0,3 \%$ SDS, $5 \% \beta$-mercaptoethanol and $10 \%$ glycerol). Finally, the solubilized membrane proteins were separated by SDS-PAGE (DeBlas et al., 1979). The fixed, unstained gels were impregnated with "Fluoro-Hance" (Research Products International), dried, and exposed to Kodak X-Omat AR film to obtain fluorographic patterns of the labeled polypeptides.

Protein was determined by the method of Markwell et al. (1978). Binding constants were determined through computer-assisted curvefitting analysis (LIGAND program) for a 2-site model (Munson and Rodbard, 1980).

\section{Results and Discussion}

\section{$A z-P C P$ binding to the rat brain $P C P$ receptor}

The binding of Az-PCP and other PCP analogs to brain synaptic membranes was determined from the displacement of a tritium- 
labeled analog by an unlabeled analog. Data from an experiment in which unlabeled Az-PCP was used to displace $\mathrm{Az}-{ }^{3} \mathrm{H}-\mathrm{PCP}$ are shown in Figure 1. Previously, we reported that PCP binds to 2 classes of sites in rat brain membranes (Blaustein and Ickowicz, 1983; Sorensen and Blaustein, 1985a). Az-PCP also binds to 2 classes of sites (Fig. 1): high-affinity sites with $K_{\mathrm{D}}=0.139 \pm$ $0.010 \mu \mathrm{M}$ and $B_{\max }=5.9 \pm 0.5 \mathrm{pmol} \mathrm{ligand} / \mathrm{mg}$ protein, and low-affinity sites with $K_{\mathrm{D}}=255 \pm 55 \mu \mathrm{M}$ and $B_{\max }=4849 \pm$ $1113 \mathrm{pmol}$ ligand $/ \mathrm{mg}$ protein (means $\pm \mathrm{SE}$ of 5 experiments). The low-affinity binding probably results from interactions between the highly hydrophobic PCP and Az-PCP molecules and the hydrophobic regions of many integral membrane proteins and lipids (Heidmann et al., 1985).

As shown in Table 1, similar values were obtained for the apparent affinity of Az-PCP for high-affinity binding to synaptic membranes irrespective of which tritiated PCP analog was used in the displaccment assay. Likewise, the apparent affinities of the other PCP analogs (PCP, TCP and $m$-amino-PCP) for these sites were similar, whether the tritiated form of the respective ligand or $\mathrm{Az}-{ }^{3} \mathrm{H}-\mathrm{PCP}$ was employed in the assay. These data indicate that Az-PCP binds with high affinity to the same brain receptor sites as those to which $\mathrm{PCP}, \mathrm{TCP}$, and $m$-amino-PCP bind.

Evidence that Az-PCP binds covalently to the high-affinity PCP receptor was obtained by showing that it inhibits subsequent ligand binding. Synaptic membranes were equilibrated in the dark with excess $(2 \mu \mathrm{M})$ unlabeled $\Lambda z$-PCP. The suspensions were then either kept in the dark or irradiated with UV to photolyze the Az-PCP. The membranes were subsequently washed to remove excess Az-PCP and were assayed for the ability to bind ${ }^{3} \mathrm{H}-\mathrm{PCP}$ or ${ }^{3} \mathrm{H}$-TCP to determine the availability of high-affinity binding sites. Irradiation in the absence of $\mathrm{Az}$ PCP reduced the available number of high-affinity sites $\left(B_{\max }\right)$ by $25 \%$; irradiation in the presence of Az-PCP produced a further reduction of $14+2 \%(n=3)$, with negligible effect on the $K_{\mathrm{D}}$. This suggests that the efficiency of covalent attachment of Az-PCP to the high-affinity sites is about $14 \%$, which seems reasonable for an aryl-substituted nitrene (Cavalla and Neff, 1985).

\section{Covalent labeling of the membrane polypeptides}

The preceding results indicate that Az-PCP binds covalently, and with high affinity, to the rat brain PCP receptor. Therefore, $\mathrm{Az}-{ }^{3} \mathrm{H}-\mathrm{PCP}$ was used to identify this receptor. Synaptic membranes were equilibrated with $1 \mu \mathrm{M} \mathrm{Az}-{ }^{3} \mathrm{H}-\mathrm{PCP}$ at $0^{\circ} \mathrm{C}$, with or without a 100- to 1000-fold excess of unlabeled PCP or TCP. [Our unpublished observations indicate that the binding of PCP and its analogs to the PCP receptor is temperature sensitive: The concentration of Az- ${ }^{3} \mathrm{H}-\mathrm{PCP}$ used $(1 \mu \mathrm{M})$ is close to the $K_{\mathrm{D}}$ for the high-affinity site $\left(0.95 \mu \mathrm{M}\right.$ at $\left.0^{\circ} \mathrm{C}\right)$, but $<1 \%$ of the $K_{\mathrm{D}}$ for the low-affinity site $\left(500 \mu \mathrm{M}\right.$ at $\left.0^{\circ} \mathrm{C}\right)$.] The radioactive ligand was then covalently attached to the membranes by photoactivation with UV light. Subsequent analysis of the solubilized membranes by SDS-PAGE and fluorography showed incorporation of radioactivity into several polypeptides (Fig. 2); nonirradiated samples did not incorporate the label (not shown). The presence of excess unlabeled PCP $(0.5 \mathrm{~mm})$ in the incubation medium clearly reduced the covalent labeling of 2 polypeptides, with apparent molecular weights $\left(M_{r}\right)$ of 80,000 and 95,000 .

The dense, $\sim 95 \mathrm{kDa}$ polypeptide band observed with Coomassie blue staining (Fig. 2, lane CB) probably corresponds to the $\alpha$ subunit of the Na,K-ATPase (Mahler, 1977; Sweadner, 1979). Control experiments with red blood cell and kidney membranes (not shown) indicate that $\mathrm{Az}^{-3} \mathrm{H}-\mathrm{PCP}$ does not label the Na,K-ATPase. Also, using an assay for solubilized membrane proteins, we found that ${ }^{3} \mathrm{H}-\mathrm{PCP}$ does not bind to purified dog kidney Na,K-ATPase (R. G. Sorensen and M. P. Blaustein, unpublished observations). Presumably, the labeled polypeptide is present in low concentration and migrates close to the $\alpha$ subunit of the Na,K-ATPase (Fig. 2).

The $80 \mathrm{kDa}$ polypeptide was only weakly labeled in some experiments (e.g., see Fig. $2 A$ ). This might suggest that it is a proteolytic cleavage product of the larger polypeptide, but inclusion of several protease inhibitors (1 mM EDTA, $0.5 \mathrm{~mm}$ phenylmethyl sulfonyl fluoride, and $2.5 \mathrm{units} / \mathrm{ml}$ aprotinin) in all solutions did not prevent labeling of the $80 \mathrm{kDa}$ polypeptide. Therefore, we favor the view that the $95 \mathrm{kDa}$ polypeptide contains the primary PCP binding site. The variable labeling of the $80 \mathrm{kDa}$ polypeptide may indicate that it lies close to the $95 \mathrm{kDa}$ polypeptide in the native membranes and, thus, may be part of the complex that makes up the PCP receptor. This would be analogous to experiments on the nicotinic $\mathrm{ACh}$ receptor (AChR), in which $\mathrm{Az}-{ }^{3} \mathrm{H}-\mathrm{PCP}$ labels most of the subunits, even though only 1 appears to contain the primary PCP binding site (Haring et al., 1983).

While the present study was in progress, Haring et al. (1986) reported that 2 polypeptides, with apparent $M_{r} 90,000$ and 33,000 , were specifically labeled by $\mathrm{Az}-{ }^{3} \mathrm{H}-\mathrm{PCP}$ and were components of the high-affinity $\mathrm{PCP}$ receptor in rat hippocampus. Three other polypeptides, with $M_{r}$ of $62,000,49,000$, and 40,000, were also labeled by $\mathrm{Az}-{ }^{3} \mathrm{H}-\mathrm{PCP}$ in their experiments; however, further pharmacological characterization led Haring et al. to propose that these 3 polypeptides represent a second PCP receptor domain distinct from the high-affinity receptor. It seems probable that their $90 \mathrm{kDa}$ polypeptide and our $95 \mathrm{kDa}$ polypeptide are the same. We also sometimes observed weak labeling of a smaller polypeptide $\left(\mathrm{M}_{\mathrm{r}}=30,000-35,000\right)$ that may have been specifically displaced by PCP (Fig. $2 B$ ), although the results are not clear. This may correspond to the $33 \mathrm{kDa}$ polypeptide described by Haring et al. In these respects, the 2 studies appear complementary. Haring et al. (1986) did not observe a specifically labeled $80 \mathrm{kDa}$ polypeptide, but part of the difference may be due to our use of rat forebrain instead of hippocampus or to variable labeling of this polypeptide (Fig. 2). The data are difficult to compare in detail, however, because Haring et al. did not publish fluorograms of their gel patterns.

PCP also binds to the nicotinic AChR (Haring and Kloog, 1984; Heidmann et al., 1985; Oswald et al., 1984) and blocks the ion channel associated with this receptor (Albuquerque et al., 1981, 1983). However, 2 observations show that the PCP receptor in brain is distinct from the nicotinic AChR. First, PCP binds to the nicotinic AChR from Torpedo electric organ membranes with a $K_{\mathrm{D}}$ of about $6 \mu \mathrm{M}$ (Haring and Kloog, 1984; Heidmann et al., 1985; Oswald et al., 1984; R. G. Sorensen and M. P. Blaustein, unpublished observations). This is 20 - to 100 -fold greater than the $K_{\mathrm{D}}$ for PCP binding to the brain receptor under comparable conditions. Second, both ${ }^{3} \mathrm{H}-\mathrm{PCP}$ and $\mathrm{Az}-{ }^{3} \mathrm{H}-\mathrm{PCP}$ covalently attach to polypeptides of apparent $M_{r} 40,000,50,000$, and 66,000 , which are the $\alpha, \beta$, and $\delta$ subunits, respectively, of the Torpedo AChR (Haring et al., 1984; Heidmann et al., 1985); we obtained similar labeling patterns with Torpedo electroplax membranes (unpublished observations). These polypeptides are different from those photolabeled by $\mathrm{Az}-{ }^{3} \mathrm{H}-\mathrm{PCP}$ in brain (Fig. 2).

TCP has a higher affinity for the brain receptor than does PCP (Table 1; see also Sorensen and Blaustein, 1985a; Vignon et al., 1983). Moreover, TCP is more potent than PCP both in its behavioral activity (Shannon, 1981; Vaupel et al., 1984) and in its ability to block presynaptic $\mathrm{K}$ channels (Bartschat and Blaustein, 1986a). Consistent with these observations, TCP also appeared to be more potent than PCP in blocking the covalent attachment of $\mathrm{Az}-{ }^{3} \mathrm{H}-\mathrm{PCP}$ to the 95 and $80 \mathrm{kDa}$ polypeptides (Fig. 2B). Scans of these fluorograms (with a Joyce-Loebl microdensitometer) indicated that, in the presence of $1 \mu \mathrm{M} \mathrm{Az}-{ }^{3} \mathrm{H}$ PCP, $100 \mu \mathrm{M}$ TCP displaced about $32 \%$ of the label in both the 95 and $80 \mathrm{kDa}$ polypeptides, while $100 \mu \mathrm{M}$ PCP displaced only about $22 \%$ of the label. The respective displacement values for 


\begin{tabular}{|c|c|}
\hline Test compound & $\begin{array}{l}K_{0.5} \text { for displacement of }{ }^{3} \mathrm{H}- \\
\text { PCP from high-affinity sites } \\
\text { (mM) }\end{array}$ \\
\hline \multicolumn{2}{|l|}{ Aminopyridines } \\
\hline 4-AP & $2.6 \pm 0.1(2)$ \\
\hline 3,4-diAP & $3.1 \pm 0.1(3)$ \\
\hline 2-AP & $8.8 \pm 1.6(3)$ \\
\hline 3-AP & $53.9 \pm 3.2(3)$ \\
\hline \multicolumn{2}{|l|}{ Tetraalkylamines } \\
\hline TBA & $1.6 \pm 0.1(2)$ \\
\hline TEA & $6.7 \pm 0.8$ \\
\hline TMA & $33.6 \pm 3.0(4)$ \\
\hline
\end{tabular}

The ability of several aminopyridines and tetraalkylamines to compete with $5 \mathrm{~nm}$ ${ }^{3} \mathrm{H}-\mathrm{PCP}$ for binding to synaptic membranes was measured as described in Materials and Methods. The $K_{0.5}$ values (mM) are the apparent half-maximal binding constants for the displacing compound (AP or TAA). The data are the means \pm SEM of $2-$ 4 experiments as indicated in the parentheses.

$1000 \mu \mathrm{M}$ TCP and PCP were about 68 and $59 \%$. This is further evidence that these 2 polypeptides are part of the high-affinity $\mathrm{PCP}$ receptor complex.

\section{Identification of the PCP receptor as a $K$ channel}

Studies in skeletal muscle (Tsai et al., 1980), cardiac muscle (Hadley and Hume, 1986), neuroblastoma (Tourneur et al., 1982), and presynaptic nerve terminals (Bartschat and Blaustein, 1986a) indicate that PCP blocks a voltage-gated K chan$\mathrm{nel}$; this is manifested by an increase in action potential duration in the muscle and neuroblastoma preparations. In ${ }^{86} \mathrm{Rb}$-loaded terminals, selective inhibition of a component of $\mathrm{Rb}$ efflux that corresponds to a voltage-gated, noninactivating $\mathrm{K}$ channel by PCP and its analogs closely parallels the behavioral potency of these agents (Bartschat and Blaustein, 1986a). Az-PCP also blocks this component of Rb efflux in nerve terminals (D. K. Bartschat and M. P. Blaustein, unpublished observations). These findings have led to the proposal that the PCP receptor in brain is a component of a $\mathrm{K}$ channel. This view is supported by the observation that the enantiomorphs of "sigma" opiate stereoisomer pairs with PCP-like behavioral effects also bind, stereospecifically, to the PCP receptor in brain membranes (Bartschat et al., 1985) and block the same presynaptic, voltage-gated K channel as does PCP (Bartschat and Blaustein, 1986b).

The data in Table 1 may provide some information about the $\mathrm{K}$ channel density in presynaptic nerve terminals, on the assumption that $1 \mathrm{PCP}$ molecule is bound per channel. The density of PCP binding sites, about $2-3 \mathrm{pmol} / \mathrm{mg}$ synaptic membrane protein, can be compared to the density of $\mathrm{Na}$ channels (i.e., saxitoxin binding sites) in somewhat less "pure" rat brain synaptic membrane preparations: $1.4-4.7 \mathrm{pmol} / \mathrm{mg}$ protein (Angelides et al., 1985; Krueger et al., 1979). These data suggest that the ratio of $\mathrm{Na}$ channels to $\mathrm{K}$ channels in rat brain synaptic membranes may not be very different from the ratio of $\mathrm{Na}$ channels to delayed rectifier $\mathrm{K}$ channels, approximately 2-5:1, in squid giant axons and frog node of Ranvier (Hille, 1984).

Some APs and some TAAs are known to block voltage-gated $\mathrm{K}$ channels (Bartschat and Blaustein, 1985; French and Shoukimas, 1981; Stanfield, 1983; Thesleff, 1980; Thompson, 1977), including those in presynaptic nerve terminals (Bartschat and Blaustein, 1985; Stanfield, 1983; Thesleff, 1980). Therefore, we tested several APs and TAAs for their ability to displace ${ }^{3} \mathrm{H}-$ PCP from its high-affinity binding sites on synaptic membranes. The results (Table 2) show that millimolar concentrations of 4-AP, TBA, and tetraethylammonium (TEA) blocked ${ }^{3} \mathrm{H}-\mathrm{PCP}$ binding to its brain receptor. Similar concentrations of these

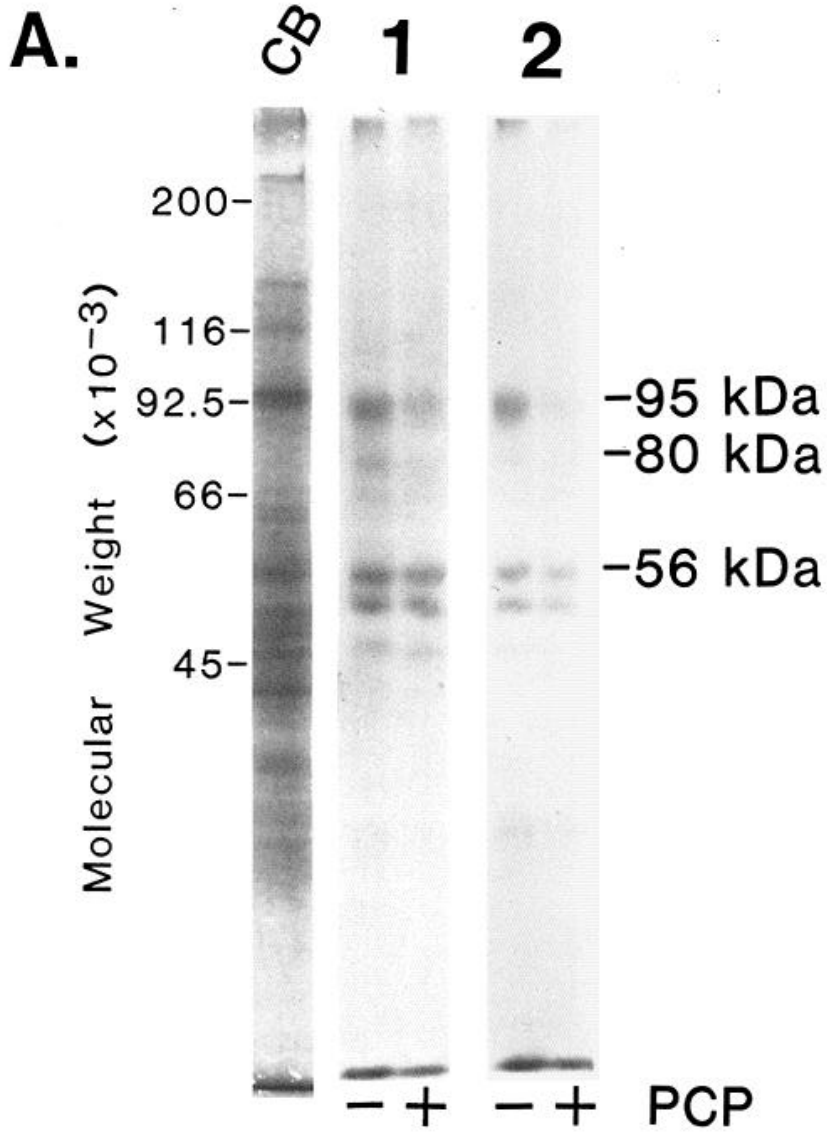

compounds are required for block of the voltage-gated, noninactivating $\mathrm{K}$ channel in presynaptic terminals (Bartschat and Blaustein, 1985). The rank orders of potency for block of ${ }^{3} \mathrm{H}-$ $\mathrm{PCP}$ binding by the APs $(4-\mathrm{AP} \simeq 3,4$-diAP $>2$-AP $\gg 3$-AP) and by the TAAs (TBA $>$ TEA $\gg$ TMA, tetramethylammonium) parallel their ability to block $\mathrm{K}$ channels and/or enhance neurotransmitter release (Bartschat and Blaustein, 1986a; French and Shoukimas, 1981; Johns et al., 1976; Moritoki et al., 1978). These data are consistent with the idea that ${ }^{3} \mathrm{H}-\mathrm{PCP}$ binds to a $\mathrm{K}$ channel.

On the basis of the foregoing observations, we examined the effects of 4-AP and TBA on the covalent labeling of synaptic membrane polypeptides by $\mathrm{Az}-{ }^{3} \mathrm{H}-\mathrm{PCP}$. As shown in Figure $2 B$, $5 \mathrm{~mm}$ 4-AP and $5 \mathrm{~mm}$ TBA both specifically blocked incorporation of label onto the 95 and $80 \mathrm{kDa}$ polypeptides. The data in Table 2 and Figure $2 B$ provide additional evidence that the rat brain PCP receptor is part of a voltage-gated, noninactivating $\mathrm{K}$ channel (Bartschat and Blaustein, 1986a). This is also supported by our observation that TBA and 4-AP are, respectively, a competitive inhibitor and an allosteric inhibitor of highaffinity PCP binding to synaptic membranes (R. G. Sorensen and M. P. Blaustein, unpublished observations). Therefore, the 95 and $80 \mathrm{kDa}$ polypeptides that we labeled with $\mathrm{Az}-{ }^{3} \mathrm{H}-\mathrm{PCP}$ appear to be subunits of both the PCP receptor and a K channel.

Intoxication with 4-AP (Spyker et al., 1980), as with PCP (Domino and Luby, 1981), causes dissociative behavior in man. These observations are consistent with the hypothesis (Albuquerque et al., 1981, 1983; Bartschat and Blaustein, 1986a) that the PCP receptor/K channel complex described in this report is involved in the behavioral disturbances generated by 4-AP and PCP. Our findings provide a means with which to initiate the purification and biochemical characterization of the PCP receptor/voltage-gated, noninactivating $\mathrm{K}$ channel from brain. 

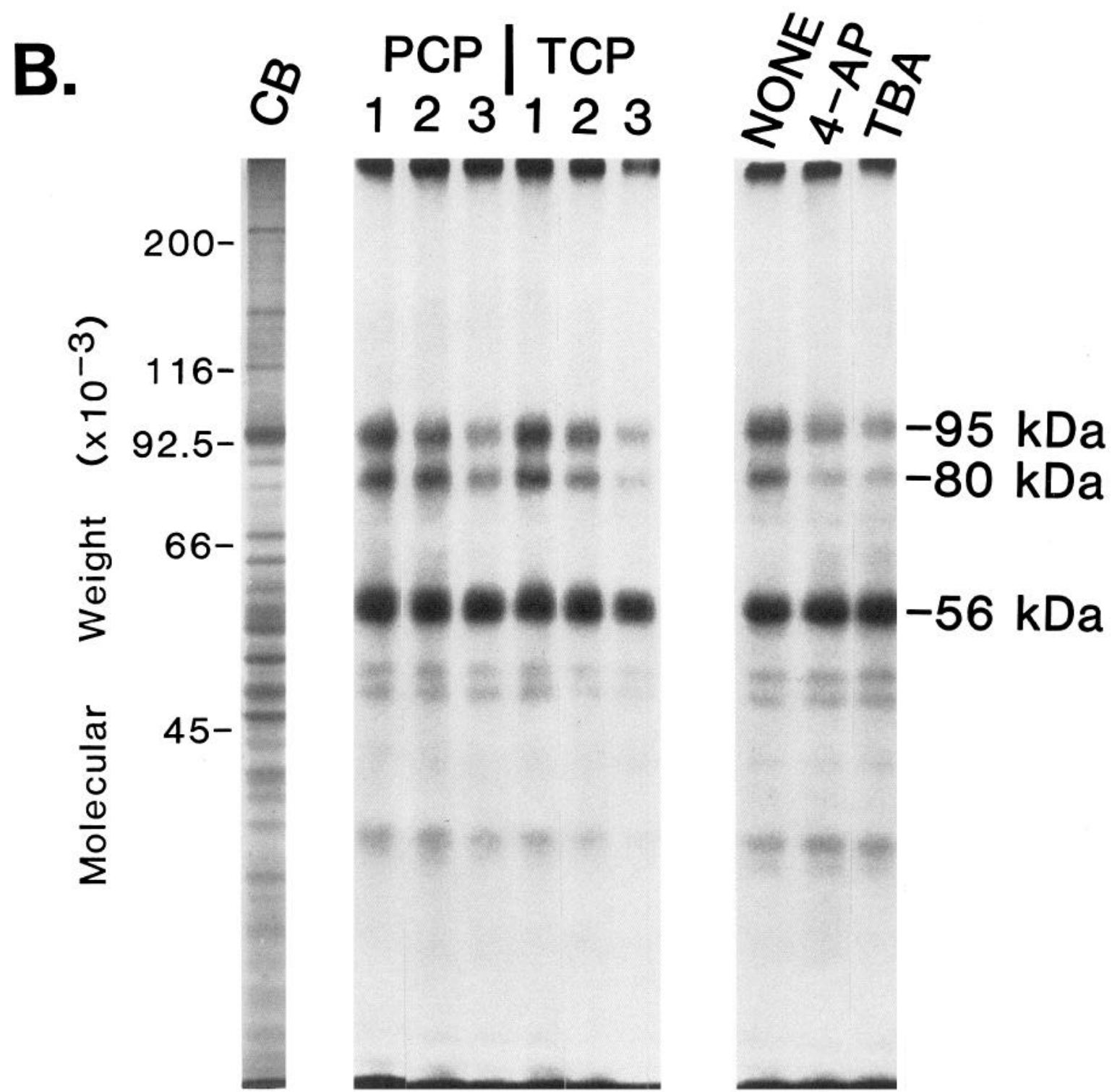

Figure 2. Fluorograms illustrating the covalent attachment of $\mathrm{Az}-{ }^{3} \mathrm{H}-\mathrm{PCP}$ to brain membrane polypeptides. $A$, Synaptic membranes $(0.63 \mathrm{mg} /$ $\mathrm{ml}$ ) were incubated in the dark at $0^{\circ} \mathrm{C}$ in either (1) $5 \mathrm{~mm}$ Tris/HEPES, pH 7.0, or (2) $5 \mathrm{~mm}$ sodium phosphate, pH 7.0, each containing $1.0 \mu \mathrm{M}$ Az- ${ }^{3} \mathrm{H}-\mathrm{PCP}$ without (-) or with (+) $0.5 \mathrm{~mm}$ unlabeled PCP. Use of $5 \mathrm{~mm}$ Tris/HEPES buffer instead of 5 mm sodium phosphate did not significantly affect the level of ligand incorporation (compare 1 and 2), whereas $50 \mathrm{~mm}$ Tris/HEPES buffer substantially reduced the level of incorporation (not shown). After $60 \mathrm{~min}$, the binding mixtures were subjected to vacuum filtration to remove excess unbound ligand. Remaining procedures are described in Materials and Methods. Covalent attachment of the analog was promoted by irradiating the filters with longwave ( $366 \mathrm{~nm}$ ) UV light for $15 \mathrm{~min}$ at a distance of $8 \mathrm{~cm}$. The molecular weights of some labeled polypeptides (numbers to the right), as well as some molecular-weight standards (numbers to the left) are indicated (in $\mathrm{kDa}$ ). $C B$ indicates the polypeptide staining (Coomassie Brilliant blue) pattern of a gel run in parallel. The results show that excess PCP blocks the covalent labeling of the 80 and $95 \mathrm{kDa}$ polypeptides but has little effect on the labeling of other membrane polypeptides such as the $56 \mathrm{kDa}$ polypeptide. $B$, Synaptic membranes $(2.1 \mathrm{mg} / \mathrm{ml})$ were subjected to covalent labeling with $1 \mu \mathrm{M}$ $\mathrm{Az}-{ }^{3} \mathrm{H}-\mathrm{PCP}$ as in $A$, in $5 \mathrm{~mm}$ sodium phosphate, pH 7.0. Further additions to the binding mixtures were: for PCP and TCP, lanes 1-3 contained 1,100 , and $1000 \mu \mathrm{M}$ unlabeled ligand, respectively; for 4-AP and TBA, 5 mм compound was added; NONE indicates that no unlabeled test substance was added. Photoactivation was induced by irradiation with shortwave $(254 \mathrm{~nm})$ UV light for 5 min. Differences in the migration rates of some of the labeled polypeptides between the fluorograms shown in $A$ and $B$ may have resulted from the use of different sources of SDS ( $A$, from Sigma, St. Louis, MO; $B$, from Bio-Rad, Richmond, $\mathrm{CA}$ ) in preparing the polyacrylamide gels.

Note added in proof: While this manuscript was in press, Petersen et al. (1986) reported that $\beta$-bungarotoxin ( $\beta$-BuTX), a presynaptically acting polypeptide toxin from the venom of the snake Bungarus multicinctus, blocks a noninactivating $\mathrm{K}$ current in guinea pig dorsal root ganglion neurons. Rehm and Betz (1983) have shown that $\beta$-BuTX labels a $95 \mathrm{kDa}$ polypeptide in chick brain membranes. These observations are consistent with the idea that the $95 \mathrm{kDa}$ polypeptide from brain membranes labeled by Az-PCP (this report) and the one labeled by $\beta$-BuTX are identical and are, as we have suggested, part of a voltage-gated, noninactivating $\mathrm{K}$ channel in presynaptic nerve terminals.

\section{References}

Albuquerque, E. X., L. G. Aguayo, J. E. Warnick, H. Weinstein, S. D. Glick, S. Maayani, R. K. Ickowicz, and M. P. Blaustein (1981) The behavioral effects of phencyclidines may be due to their blockade of potassium channels. Proc. Natl. Acad. Sci. USA 78: 7792-7796.

Albuquerque, E. X., J. E. Warnick, L. G. Aguayo, R. K. Ickowicz, M. P. Blaustein, S. Maayani, and H. Weinstein (1983) Phencyclidine: 
Differentiation of behaviorally active from inactive analogs based on interactions with channels of electrically excitable membranes and of cholinergic receptors. In Phencyclidine and Related Arylcyclohexylamines: Present and Future Applications, J. M. Kamenka, E. F. Domino, and P. Geneste, eds., pp. 579-594, NPP Books, Ann Arbor, MI.

Angelides, K. J., T. J. Nutter, L. W. Elmer, and E. S. Kempner (1985) Functional unit size of the neurotoxin receptors on the voltage-dependent sodium channel. J. Biol. Chem. 260: 3431-3439.

Bartschat, D. K., and M. P. Blaustein (1985) Potassium channels in isolated presynaptic nerve terminals from rat brain. J. Physiol. (Lond.) 361: 419-440.

Bartschat, D. K., and M. P. Blaustein (1986a) Phencyclidine in low doses selectively blocks a presynaptic voltage-regulated potassium channel in rat brain. Proc. Natl. Acad. Sci. USA 83: 189-192.

Bartschat, D. K., and M. P. Blaustein (1986b) Certain "sigma" opiate stereoisomer pairs have opposite actions on potassium (K) pcrmeabilities in rat presynaptic nerve terminals. J. Physiol. (Lond.) 371 . 202p.

Bartschat, D. K., R. G. Sorensen, and M. P. Blaustein (1985) Psychotomimetic "sigma opiates" and phencyclidines selectively block the same K channels in presynaptic nerve terminals. Soc. Neurosci. Abstr. 11: 316 .

Blaustein, M. P., and R. Ickowicz (1983) Phencyclidine in nanomolar concentrations binds to synaptosomes and blocks certain potassium channels. Proc. Natl. Acad. Sci. USA 80: 3855-3859.

Cavalla, D., and N. H. Neff (1985) Chemical mechanisms for photoaffinity labeling of receptors. Biochem. Pharmacol. 34: 2821-2826.

DeBlas, A. L., Y.-J. Wang, R. Sorensen, and H. R. Mahler (1979) Protein phosphorylation in synaptic membranes regulated by adenosine $3^{\prime}: 5^{\prime}$-monophosphate: Regional and subcellular distribution of the endogenous substrates. J. Neurochem. 33: 647-659.

DeTraglia, M. C., J. S. Brand, and A. M. Tometsko (1978) Characterization of azidobenzamidines as photoaffinity labels for trypsin. $\mathrm{J}$. Biol. Chem. 253: 1846-1852.

Domino, E. F., and E. D. Luby (1981) Abnormal mental states induced by phencyclidine as a model of schizophrenia. In PCP (Phencyclidine): Historical and Current Perspectives, E. F. Domino, ed., pp. 401-418, NPP Books, Ann Arbor, MI.

French, R. J., and J. Shoukimas (1981) Blockage of squid axon potassium conductance by internal tetra- $\mathrm{N}$-alkylammonium ions of various sizes. Biophys. J. 34: 271-291.

Hadley, R. W., and J. R. Hume (1986) Actions of phencyclidine on the action potential and membrane currents of single guinea pig myocytes. J. Pharmacol. Exp. Ther. 237: 131-136.

Hampton, R. Y., F. Medzihradsky, J. H. Woods, and P. J. Dahlstrom (1982) Stereospecific binding of ${ }^{3} \mathrm{H}$-phencyclidine in brain membranes. Life Sci. 30: 2147-2154.

Haring, R., and Y. Kloog (1984) Multiple binding sites for phencyclidine on the nicotinic acetylcholine receptor from Torpedo ocellata electric organ. Life Sci. 34: 1047-1055.

Haring, R., Y. Kloog, A. Kalir, and M. Sokolovsky (1983) Species differences determine azido phencyclidine labeling pattern in desensitized nicotinic acetylcholine receptors. Biochem. Biophys. Res. Commun. 113: 723-729.

Haring, R., Y. Kloog, and M. Sokolovsky (1984) Localization of phencyclidine binding sites on $\alpha$ and $\beta$ subunits of the nicotinic acetylcholine receptor from Torpedo ocellata electric organ using azido phencyclidinc. J. Neurosci. 4: 627-637.

Haring, R., Y. Kloog, and M. Sokolovsky (1986) Identification of polypeptides of the phencyclidine (PCP) receptor of rat hippocampus by photoaffinity labeling with $\left[{ }^{3} \mathrm{H}\right]$ azidophencyclidine. Biochemistry 25: 612-620.

Heidmann, T., R. E. Oswald, and J.-P. Changeux (1985) Multiple sites of action for noncompetitive blockers on acetylcholine receptor rich membrane fragments from Torpedo marmorata. Biochemistry 22: $3112-3127$.

Hille, B., ed. (1984) In Ionic Channels of Excitable Membranes, Sinauer Assoc., Sunderland, MA.

Johns, A., D. S. Golko, P. A. Lauzon, and D. M. Paton (1976) The potentiating effects of 4-aminopyridine on adrenergic transmission in the rabbit vas deferens. Eur. J. Pharmacol. 38: 71-78.

Krueger, B. K., R. W. Ratzlaff, G. R. Strichartz, and M. P. Blaustein (1979) Saxitoxin binding to synaptosomes, membranes, and solubilized binding sites from rat brain. J. Membr. Biol. 50: 287-310.

Lazdunski, M., J. N. Bidard, G. Romey, Y. Tourneur, J. Vignon, and J. P. Vincent (1983) The different sites of action of phencyclidine and its analogues in nervous tissue. In Phencyclidine and Related
Arylcyclohexylamines: Present and Future Applications, J. M. Kamenka, E. F. Domino, and P. Geneste, eds., pp. 83-106, NPP Books, Ann Arbor, MI

Mahler, H. R. (1977) Proteins of the synaptic membrane. Neurochem. Res. 2: 119-147.

Markwell, M. A., S. M. Haas, L. L. Bieber, and N. E. Tolbert (1978) A modification of the Lowry procedure to simplify protein determination in membrane and lipoprotein samples. Anal. Biochem. 87: 206-210.

Mendelsohn, L. G., G. A. Kerchner, V. Kalra, D. M. Zimmerman, and J. P. Leander (1984) Phencyclidine receptors in rat brain cortex. Biochem. Pharmacol. 33: 3529-3535.

Moritoki, H., M. Takei, N. Nakamoto, and Y. Ishida (1978) Actions of aminopyridines on guinea-pig ileum. Arch. Int. Pharmacodyn. 232: 28-41.

Munson, P. J., and D. Rodbard (1980) LIGAND: A versatile computerized approach for characterization of ligand-binding systems. Anal. Biochem. 107: 220-239.

Oswald, R. E., M. J. Bamberger, and J. T. McLaughlin (1984) Mechanism of phencyclidine binding to the acetylcholine receptor from Torpedo electroplaque. Mol. Pharmacol. 25: 360-368.

Petersen, M., R. Penner, F.-K. Pierau, and F. Dreyer (1986) $\beta$-Bungarotoxin inhibits a non-inactivating potassium current in guinea pig dorsal root ganglion neurones. Neurosci. Lett. 68: 141-145.

Rehm, H., and H. Betz (1983) Identification by cross-linking of a betabungarotoxin binding polypeptide in chick brain membranes. EMBO J. 2: 1119-1122.

Salvaterra, P. M., and D. A. Matthews (1980) Isolation of rat brain subcellular fraction enriched in putative neurotransmitter receptors and synaptic junctions. Neurochem. Res. 5: 181-195.

Shannon, H. E. (1981) Evaluation of phencyclidine analogs on the basis of their discriminative stimulus properties in the rat. J. Pharmacol. Exp. Ther. 216: 543-551.

Sorensen, R. G., and M. P. Blaustein (1985a) The rat brain phencyclidine receptor is a $\mathrm{K}$ channel. Biophys. J. 47: 384a.

Sorensen, R. G., and M. P. Blaustein (1985b) The rat brain phencyclidine receptor consists of two polypeptides $\left(M_{R}=95 \mathrm{kD}\right.$ and 80 kD) that are specifically labelled by ${ }^{3} \mathrm{H}$-azido-phencyclidine. Soc. Neurosci. Abstr. 11: 316 .

Spyker, D. A., C. Lynch, J. Shobanowitz, and J. A. Sinn (1980) Poisoning with 4-aminopyridine: Report of three cases. Clin. Toxicol. 16: 487-497.

Stanfield, P. R. (1983) Tetraethylammonium ions and the potassium permeability of excitable cells. Rev. Physiol. Biochem. Pharmacol. 97: 1-67.

Sweadner, K. J. (1979) Two molecular forms of $\left(\mathrm{Na}^{+}+\mathrm{K}^{+}\right)$-stimulated ATPase in brain: Separation, and difference in affinity for strophanthidin. J. Biol. Chem. 254: 6060-6067.

Thesleff, S. (1980) Aminopyridines and synaptic transmission. Neuroscience 5: 1413-1419.

Thompson, S. H. (1977) Three pharmacologically distinct potassium channels in molluscan neurones. J. Physiol. (Lond.) 265: 465-488.

Tourneur, Y., G. Romey, and M. Lazdunski (1982) Phencyclidine blockade of sodium and potassium channels in neuroblastoma cells. Brain Res. 245: 154-158.

Tsai, M. C., E. X. Albuquerque, R. S. Aronstam, A. T. Eldefrawi, M. E. Eldefrawi, and D. J. Triggle (1980) Sites of action of phencyclidine. I. Effects on the electrical cxcitability and chemosensitive properties of the neuromuscular junction of skeletal muscle. Mol. Pharmacol. 18: 159-166.

Vaupel, D. B., D. McCoun, and E. J. Cone (1984) Phencyclidine analogs and precursors: Rotarod and lethal dose studies in the mouse. J. Pharmacol. Exp. Ther. 230: 20-27.

Vignon, J., R. Chicheportiche, M. Chicheportiche, J. M. Kamenka, P. Geneste, and M. Lazdunski (1983) [ $\left.{ }^{3} \mathrm{H}\right] \mathrm{TCP}$ : A new tool with high affinity for the PCP receptor in rat brain. Brain Res. 280: 194-197.

Vincent, J. P., J. N. Bidard, M. Lazdunski, G. Romey, Y. Tourneur, and J. Vignon (1983) Identification and properties of phencyclidinebinding sites in nervous tissues. Fed. Proc. 42: 2570-2573.

Zukin, S. R., and R.S. Zukin (1979) Specific [ $\left.{ }^{3} \mathrm{H}\right]$ phencyclidine binding in rat central nervous system. Proc. Natl. Acad. Sci. USA 76: 53725376 .

Zukin, S. R., M. L. Fitz-Syage, R. Nichtenhauser, and R. S. Zukin (1983) Specific binding of $\left[{ }^{3} \mathrm{H}\right]$ phencyclidine in rat central nervous tissue: Further characterization and technical considerations. Brain Res. 258: 277-284. 